P-ISSN: 2774-4574; E-ISSN: 2774-4582 TRILOGI, 2(1), Januari-April 2021 (6-14) @2021 Lembaga Penerbitan, Penelitian, dan Pengabdian kepada Masyarakat (LP3M) Universitas Nurul Jadid Paiton Probolinggo DOI: https://doi.org/

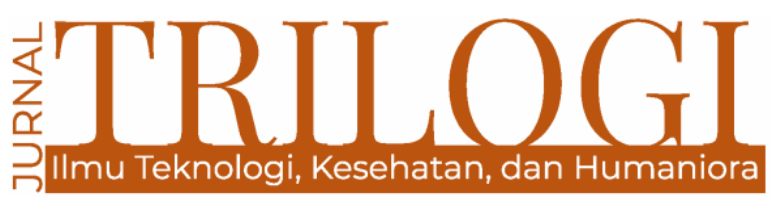

\title{
PERSPEKTIF SISWA \\ TENTANG PROSES PENGAJARAN \\ DAN PEMBELAJARAN BAHASA INGGRIS DI MI AZZAINIYAH II
}

\author{
Syaiful Islam \\ Universitas Nurul Jadid \\ syaifulislam182@gmail.com \\ Muhammad Imamuddin Al Faqih \\ Universitas Nurul Jadid \\ muhammadimam014@gmail.com
}

\section{Agie Syahraen}

Universitas Nurul Jadid

erielagie@gmail.com

\begin{abstract}
Learning English does not only apply to junior high school or high school, but can be started from elementary school. Early childhood students must learn English early to prepare them for the era of globalization. There are four problem formulations studied, namely about 1) the qualifications of English teachers, 2) students' attitudes towards English, 3) the techniques used, and 4) the media. This study used a qualitative descriptive design. The research subjects consisted of a teacher and 26 fifth grade students (V) of MI Azzainiyah II Paiton Probolinggo. There are three data collection instruments, namely observation, interviews and questionnaires. Observations are made when teaching and learning activities are in progress. After that, interviews with teachers were conducted to obtain information related to problem formulations. The questionnaire was given to students to find out students' attitudes towards English. The results showed that 1 ) the qualifications of the English teachers had good qualifications, 2) the students' attitudes towards English were very positive, 3) the techniques used were varied, including Listen-Do, Listen-Repeat, and Question and Answer, and 4) media that used in the form of pictures from various sources as well as blackboards.
\end{abstract}

Keywords: Teaching, learning, young learner

\section{Abstrak}

Pembelajaran Bahasa Inggris tidak hanya berlaku untuk sekolah menengah pertama atau atas, tetapi bisa dimulai dari sekolah dasar. Peserta didik usia dini haruslah belajar Bahasa Inggris lebih awal untuk mempersiapkan mereka menghadapi era globalisasi. Ada empat rumusan masalah yang diteliti, yaitu tentang 1) kualifikasi guru Bahasa Inggris, 2)sikap siswa terhadap Bahasa Inggris, 3) teknik yang digunakan, dan 4) media. Penelitian ini 
menggunakan rancangan deskriptif kualitatif. Subjek penelitiannya terdiri dari seorang guru dan 26 siswa kelas lima (V) MI Azzainiyah II Paiton Probolinggo. Adapun instrumen pengumpulan data ada tiga, yaitu observasi, wawancara dan kuesioner. Observasi dilakukan ketika kegiatan belajar mengajar sedang berlangsung. Setelah itu, wawancara terhadap guru dilaksanakan guna mendapat informasi terkait rumusan masalah. Kuesioner diberikan kepada siswa untuk mengetahui sikap siswa terhadap Bahasa Inggris.

Hasil penelitian menunjukkan bahwa 1) kualifikasi guru Bahasa Inggris memiliki kualifikasi yang bagus, 2) sikap siswa terhadap Bahasa Inggris sangat positif, 3) teknik yang digunakan bervariasi, diantaranya Listen-Do, Listen-Repeat, dan Tanya Jawab, dan 4) media yang digunakan berupa gambar-gambar dari berbagai sumber serta papan tulis.

Katakunci: Pengajaran, Pembelajaran, Usia dini

\section{Pendahuluan}

Bahasa Inggris merupakan salah satu bahasa internasional. Mempelajari Bahasa Inggris adalah kunci untuk menguasai teknologi dan pengetahuan kekinian (Rahman, 2015). Oleh karena itu, pemerintah menjadikan Bahasa Inggris sebagai muatan lokal untuk sekolah dasar. Hal ini bertujuan untuk mengajari siswa ekspresi secara tertulis dan lisan sederhana. Oleh karena itu, tujuan pengajaran Bahasa Inggris di sekolah adalah untuk mengembangkan kemampuan siswa dalam berkomunikasi secara tertulis ataupun lisan.

Mengajari Bahasa inggris di tingkat sekolah dasar menjadi sebuah keharusan karena didukung oleh kebijakan pemerintah. Peraturan kementerian pendidikan dan kebudayaan (RI/No.0487/4/1992, pasal VII) menyatakan bahwa sekolah dasar bisa menambahkan beberapa mata pelajaran selama sejalan dengan tujuan pendidikan nasional. Pengajaran Bahasa Inggris di Indonesia adalah untuk menyerap ilmu pengetahuan, teknologi dan seni untuk perkembangan bangsa serta untuk membangun hubungan yang baik dengan dunia internasional.

Untuk mengajar Bahasa Inggris dengan baik, perlunya mempertimbangkan beberapa faktor dalam proses kegiatan pembelajaran dan pengajaran termasuk buku, media pembelajaran serta guru yang kompeten (Hidayat \& Palupi, 2013). Persyaratan yang lain adalah lingkungan yang mendukung seperti keluarga yang akan membantu perkembangan kebahasaan anak mereka (Suardi, Ramadhan, \& Asri, 2019). Bentuk dukungan orang tua dengan memberikan fasilitas yang mendukung seperti buku-buku bacaaan berbahasa inggris, kamus, gambar-gambar, permainan dan menunjukkan perhatian kepada putra/inya ketika menonton film berbahasa inggris, mendengarkan lagu-lagu inggris atau ketika mereka mendapatkan nilai baik atau buruk dalam mata pelajaran bahasa inggris

Ada enam alasan mengapa anak-anak bisa mendapatkan keuntungan dari belajar bahasa asing (Rachmawati, 2019). Pertama, hal ini bisa mengembangkan kemampuan komunikasi dasar anak dalam bahasa. Kedua, bisa mendorong dan memotivasi mereka untuk belajar bahasa asing. Ketiga, bahasa asing bisa memperkenalkan budaya luar. Keempat, ini membnatu mengembangkan kognitif anak-anak. Kelima, untuk mengembangkan kesadaran metalinguistic. Dan yang terakhir adalah menumbuhkan semangat belajar. Anak-anak adalah masa yang paling tepat untuk mempelajari bahasa asing karena otot lidah masih dalam tahap pengembangan sehingga mudah bagi mereka untuk meniru ejaan yang betul dari bahasa asing tersebut (Arumsari, Arifin, \& Rusnalasari, 2017).

Mengajar Bahasa Inggris bisa lebih efektif karena anak-anak masih dalam masa berkembang, masa dimana mereka siap untuk belajar sebuah bahasa. Hal ini sudah menunjukkan bahwa anak-anak telah memiliki kecerdasan bahasa (Suarca, Soetjiningsih, \& Ardjana, 2016). Oleh karena itu, para pendidik harus memulai memberikan pelajaran bahasa Inggris sedini mungkin. Dengan harapan, semakin cepat kita memulai, semakin banyak yang kita dapat.

Dari pembahasan diatas, peneliti melaksanakan penelitian yang berkaitan dengan pengajaran bahasa inggris di tingkat sekolah dasar. Dengan mengemukakan lima hal yang akan menjadi pokok penelitiaan yaitu; 1) kualifikasi guru bahasa inggris, 2) sikap peserta didik terhadap pengajaran dan pembelajaran bahasa inggris, 3) teknik pengajaran yang digunakan, 4) media yang digunakan, dan 5) hasil evaluasi. 


\section{Metode}

Penelitian ini menggunakan design deskriptif kualitatif. Penelitian deskriptif ini untuk menggambarkan sebuah fenomena. Penelitian deskriptif dilakukan untuk menguji hipotesis atau menjawab pertanyaan sesuai dengan lingkup penelitian tersebut (Rukajat, 2018). Dalam penelitian kualitatif, peneliti terlibat langsung dalam penelitiannya. Hal ini berarti peneliti kualitatif berada dalam lingkungan penelitian yang alami tanpa adanya manipulasi.

Objek penelitian ini adalah seorang guru Bahasa Inggris dan siswa kelas lima (V) di MI Azzainiyah II Paiton Probolinggo yang berjumlah 26. Mata pelajaran Bahasa Inggris sendiri sudah diajarkan di kelas empat (IV). Instrumen penelitian berupa observasi, kuesioner, wawancara dan dokumentasi. Proses pengambilan data dimulai dengan mengamati kegiatan belajar mengajar dikelas. Tujuannya adalah untuk menyesuaikan jawaban di kuesioner. Nunan menyatakan bahwa kuesioner adalah instrument yang paling sering digunakan dalam penelitian yang bentuknya berupa kumpulan pertanyaan (Siyoto \& Sodik, 2015). Kuesioner digunakan untuk mengambil data dari siswa.

Kuesioner terdiri dari 10 item dengan masingmasing pertanyaan memiliki tujuan. 1) sikap siswa terhadap Bahasa Inggris, 2) respon siswa terhadap materi Bahasa Inggris, 3) sikap siswa dalam proses belajar mengajar, 4) ketertarikan siswa dalam berbicara Bahasa Inggris, 5) keaktifan siswa mempelajari modul dirumah, 6) keaktifan siswa dalam bertanya, 7) partisipasi siswa didalam kelas, 8) pengetahuan siswa bahwa Bahasa Inggris Penting untuk masa depan, 9) sikap siswa terhadap cara guru mengajar, dan 10) sikap siswa terhadap pembelajaran Bahasa Inggris. Kuesioner dalam bentuk Bahasa Indonesia.

Dan tak lupa, peneliti menggunakan teknik wawancara dimana peneliti bertanya kepada guru Bahasa Inggris dan siswa MI Azzainiyah II Paiton Probolinggo. Wawancara ini bertujuan mendapatkan informasi tambahan mengenai proses pengajaran dan pembelajaran dan kualifikasi guru tersebut.

Peneliti menggunakan observasi untuk mengumpulkan data selama proses pengajaran dan pembelajaran dengan mendatangi kelas dan mengamati cara guru mengajar terutama ketika dia menggunakan teknik pembelajaran. Prosedur pengumpulan data dibagi 2 bagian. Pertama, peneliti memberikan kuesioner kepada siswa. Kedua, peneliti mewawancarai guru untuk mendapatkan informasi tentang; 1) kulaifikasi guru, 2) teknik pengajaran, 3) materi 8 pembelajaran, 4) media yang digunakan, dan 5) evaluasi yang dilakukan. Setelah kuesioner dan wawancara terjawab, peneliti melanjutkan dengan mencocokkan jawaban tersebut dengan kondisi riil di kelas.

\section{Hasil dan Pembahasan}

\section{Hasil Penelitian}

a. Kualifikasi Guru

Kualifikasi Guru didasarkan pada pengalaman mengajar dan latar belakang pendidikan guru. Menurut New teacher Training Act, seseorang dianggap sebagai seorang guru yang kompeten apabila telah memenuhi dua persyaratan berikut; pertama, dia adalah lulusan perguruan tinggi, dan yang kedua, dia menempuh jurusan pendidikan. Dari hasil wawancara, Guru Bahasa Inggris adalah Iulusan S-1 PGSD dari Universitas Terbuka. Dia telah mengajar Bahasa Inggris sejak tahun 2004. b. Sikap Peserta Didik Terhadap Pengajaran Dan Pembelajaran Bahasa Inggris

Sikap merupakan kecenderungan pola tingkah laku individu untuk berbuat sesuatu dengan cara tertentu terhadap orang, benda atau gagasan. Sikap dapat diartikan sekelompok keyakinan dan perasaan yang melekat tentang objek tertentu dan kecenderungan untuk bertindak terhadap objek tersebut dengan cara tertentu.

Menurut Azwar, sikap terdiri atas 3 komponen yang saling menunjang yaitu:

1) Komponen kognitif merupakan representasi apa yang dipercayai oleh individu pemilik sikap, komponen kognitif berisi kepercayaan stereotipe yang dimiliki individu mengenai sesuatu dapat disamakan penanganan (opini) terutama apabila menyangkut masalah isu atau problem yang kontroversial.

2) Komponen afektif merupakan perasaan yang menyangkut aspek emosional. Aspek emosional inilah yang biasanya berakar paling dalam sebagai komponen sikap dan merupakan aspek yang paling bertahan terhadap pengaruh-pengaruh yang mungkin adalah mengubah sikap seseorang komponen afektif disamakan dengan perasaan yang dimiliki seseorang terhadap sesuatu.

3) Komponen konatif merupakan aspek kecenderungan berperilaku tertentu sesuai dengan sikap yang dimiliki oleh seseorang. Dan berisi tendensi atau kecenderungan untuk bertindak / bereaksi terhadap sesuatu dengan cara-cara tertentu. Dan berkaitan dengan objek yang dihadapinya adalah logis untuk mengharapkan bahwa sikap seseorang adalah 
dicerminkan dalam bentuk tendensi perilaku (Rijal \& Bachtiar, 2015).

Sikap peserta didik dalam hal ini dibagi menjadi 10 berdasarkan kuesioner yaitu, 1) sikap siswa terhadap Bahasa Inggris, 2) respon siswa terhadap materi Bahasa Inggris, 3) sikap siswa dalam proses belajar mengajar, 4) ketertarikan siswa dalam berbicara Bahasa Inggris, 5) keaktifan siswa mempelajari modul dirumah, 6) keaktifan siswa dalam bertanya, 7) partisipasi siswa didalam kelas, 8) pengetahuan siswa bahwa Bahasa Inggris Penting untuk masa depan, 9) sikap siswa terhadap cara guru mengajar, dan 10) sikap siswa terhadap pembelajaran Bahasa Inggris

Data tentang sikap siswa terhadap Bahasa Inggris. Hasilnya tergambarkan tabel dibawah.

Table 1. Sikap Siswa Terhadap Bahasa Inggris

1. Apakah kamu suka mata pelajaran Bahasa Inggris?

\begin{tabular}{llcc}
\hline No & Pilihan Jawaban & F & Persentase \\
\hline 1 & Sangat Suka & 15 & 57.69 \\
\hline 2 & Suka & 6 & 23.08 \\
\hline 3 & $\begin{array}{l}\text { Sedang-sedang } \\
\text { saja }\end{array}$ & 5 & 19.23 \\
\hline 4 & Tidak Suka & - & - \\
\hline 5 & Sangat Tidak Suka & - & - \\
\hline \multicolumn{2}{l}{ Total } & 26 & 100 \\
\hline
\end{tabular}

Tabel diatas menunjukkan $58 \%$ sangat suka Bahasa Inggris, $57 \%$ sangat suka Bahasa Inggris dan $19 \%$ sedang-sedang saja.

Table 2. Respon Siswa Terhadap Materi Bahasa Inggris

2. Bagaimana pendapatmu tentang materi Bahasa Inggris?

\begin{tabular}{llcl}
\hline No & Pilihan Jawaban & F & Persentase \\
\hline 1 & Sangat menikmati & 14 & 53.84 \\
\hline 2 & Menikmati & 12 & 46.16 \\
\hline 3 & Sedang-sedang & - & - \\
& saja & & \\
\hline 4 & Tidak menikmati & - & - \\
\hline 5 & Membosankan & - & - \\
\hline & Total & 26 & 100 \\
\hline
\end{tabular}

Tabel diatas menunjukkan 54\% memberikan respon sangat positif tentang materi Bahasa Inggris dan $46 \%$ responnya positif

Table 3. Sikap Siswa tentang Proses Belajar Mengajar

3. Bagaimana keadaan kelasmu ketika pembelajaran Bahasa Inggris?

\begin{tabular}{llcc}
\hline No & $\begin{array}{l}\text { Pilihan } \\
\text { Jawaban }\end{array}$ & F & Persentase \\
\hline 1 & $\begin{array}{l}\text { Sangat } \\
\text { Menyenangkan }\end{array}$ & 14 & 53.84 \\
\hline 2 & Menyenangkan & 8 & 30.77 \\
\hline
\end{tabular}

\begin{tabular}{llll}
\hline 3 & Biasa saja & 3 & 11.54 \\
\hline 4 & $\begin{array}{l}\text { Tidak } \\
\text { menyenangkan }\end{array}$ & 1 & 3.85 \\
\hline 5 & Membosankan & - & - \\
\hline & Total & 26 & 100 \\
\hline
\end{tabular}

Dari tabel diatas bisa dilihat bahwa lebih dari separuh siswa menyatakan suasana kelas sangat menyenangkan ketika pembelajaran Bahasa Inggris (53\%). 31\% menyatakan menyenangkan, $12 \%$ menyatakan biasa saja dan $4 \%$ menyatakan tidak menyenangkan.

Table 4. Ketertarikan Siswa Berbicara Bahasa Inggris

4. Kamu ingin bicara Bahsa Inggris dengan lancar?

\begin{tabular}{|c|c|c|c|}
\hline No & Pilihan Jawaban & $\mathbf{F}$ & Persentase \\
\hline 1 & Ingin Sekali 23 & & 88.46 \\
\hline 2 & Ingin & & 11.54 \\
\hline 3 & Biasa saja & & - \\
\hline 4 & Tidak Ingin & & - \\
\hline 5 & Sangat tidak ingin- & & - \\
\hline & Total 26 & & 100 \\
\hline
\end{tabular}
menggambarkan keinginan dan harapan. Dari 26 siswa, 23 diantaranya ingin sekali bisa berbahasa inggris dengan lancer (88\%). Sedangkan sisanya hanya ingin saja (12\%). Dan tak satupun yang tidak ingin berbahasa inggris.

Table 5. Keaktifan Siswa belajar Bahasa Inggris dirumah

5. Apakah kamu belajar bahasa inggris dirumah?

\begin{tabular}{llll}
\hline No & $\begin{array}{l}\text { Pilihan } \\
\text { Jawaban }\end{array}$ & F & Persentase \\
\hline 1 & Selalu & 7 & 26.92 \\
\hline 2 & Sering & 6 & 23.08 \\
\hline 3 & Jarang & 8 & 30.77 \\
\hline 4 & $\begin{array}{l}\text { Kadang- } \\
\text { kadang }\end{array}$ & 3 & 11.54 \\
\hline 4 & Tidak pernah & 2 & 7.69 \\
\hline & Total & 26 & 100 \\
\hline
\end{tabular}

Tabel diatas menunjukkan 7 siswa selalu belajar, 6 siswa sering belajar, 8 siswa jarang belajar, 3 siswa kadang-kadang belajar dan 2 siswa tidak perrnah belajar.

Tabel 6. Keaktifan Siswa Untuk Bertanya 6. Apakah kamu tidak paham materi inggris?

\begin{tabular}{llll} 
No & $\begin{array}{l}\text { Pilihan } \\
\text { Jawaban }\end{array}$ & F & Persentase \\
\hline 1 & Selalu & 4 & 15.38 \\
\hline 2 & Sering & 9 & 34.61 \\
\hline 3 & Jarang & 1 & 3.84 \\
\hline 4 & $\begin{array}{l}\text { Kadang- } \\
\text { kadang }\end{array}$ & 12 & 46.15 \\
\hline 5 & Tidak pernah & - & - \\
\hline & Total & 26 & 100 \\
\hline
\end{tabular}

Dari table diatas, bisa disimpulkan bahwa semua siswa aktif dalam bertanya walaupun frekuensinya berbeda. 4 siswa selalu bertanya, 9 
siswa sering, 1 siswa jarang dan 12 siswa kadangkadang bertanya.

Tabel 7. Partisispasi Siswa dikelas 7. Apakah kamu aktif dikelas?

\begin{tabular}{llll}
\hline No & $\begin{array}{l}\text { Pilihan } \\
\text { Jawaban }\end{array}$ & $\mathbf{F}$ & Persentase \\
\hline 1 & Selalu & 13 & 50 \\
\hline 2 & Sering & 6 & 23.08 \\
\hline 3 & Jarang & 2 & 7.69 \\
\hline 4 & $\begin{array}{l}\text { Kadang- } \\
\text { kadang }\end{array}$ & 5 & 19.23 \\
\hline 5 & Tidak pernah & - & - \\
\hline & Total & 26 & 100 \\
\hline
\end{tabular}

Tabel diatas menunjukkan 50\% siswa selalu aktif berpartisipasi dikelas, 6 siswa sering, 2 siswa jarang berpartisipasi dan 5 siswa kadang-kadang. Secara keseluruhan, semua siswa berpartisipasi dikelas dengan frekuensi yang berbeda.

Table 8. Sikap Siswa Tentang Kegunaan Bahasa Inggris

8. Apakah menurut kamu bahasa inggris itu berguna di masa depan?

\begin{tabular}{llll}
\hline No & $\begin{array}{l}\text { Pilihan } \\
\text { Jawaban }\end{array}$ & F & Persentase \\
\hline 1 & $\begin{array}{l}\text { Sangat } \\
\text { Berguna }\end{array}$ & 20 & 76.93 \\
\hline 2 & Berguna & 5 & 19.23 \\
\hline 3 & Biasa saja & 1 & 3.84 \\
\hline 4 & Percuma & - & - \\
\hline 5 & $\begin{array}{l}\text { Sangat } \\
\text { Percuma }\end{array}$ & - & - \\
\hline \multicolumn{5}{c}{ Total } & 26 & 100 \\
\hline Bisa dikatakan bahwa, sebagian besar siswa \\
meyakini bahasa inggris sangat berguna bagi \\
masa depan mereka yaitu dengan 20 siswa \\
memilih. 5 siswa yang lain menganggap berguna \\
dan 1 siswa tersisa memilih biasa saja.
\end{tabular}

Tabel 9. sikap siswa terhadap cara guru mengajar

9. Apakah kalian suka cara mengajar guru bahasa inggris kalian?

\begin{tabular}{llll}
\hline No & $\begin{array}{l}\text { Pilihan } \\
\text { Jawaban }\end{array}$ & F & Persentase \\
\hline 1 & Sangat Suka & 10 & 38.46 \\
\hline 2 & Suka & 14 & 53.84 \\
\hline 3 & Biasa saja & 1 & 3.84 \\
\hline 4 & Tidak suka & 1 & 3.84 \\
\hline 5 & $\begin{array}{l}\text { Sangat tidak } \\
\text { suka }\end{array}$ & - \\
\hline & \multicolumn{4}{c}{26} \\
\hline
\end{tabular}

Tabel 10. sikap siswa terhadap bahasa inggris 10
10. Menurut kalian, apakah bahasa inggris sulit dipahami?

\begin{tabular}{llll}
\hline No & $\begin{array}{l}\text { Pilihan } \\
\text { Jawaban }\end{array}$ & F & Persentase \\
\hline 1 & Sangat Sulit & 2 & 7.69 \\
\hline 2 & Sulit & 4 & 15.38 \\
\hline 3 & Biasa saja & 5 & 19.23 \\
\hline 4 & Mudah & 5 & 19.23 \\
\hline 5 & Sangat mudah & 10 & 38.46 \\
\hline & Total & 26 & 100 \\
\hline
\end{tabular}

belajar bahasa inggris. 2 yang lain malah menyattakan sangat sulit. Akan tetapi, sebagian besar menyatakan bisa memahami bahasa inggris. 5 siswa menyatakan mudah. 10 siswa menyatakan sangat mudah dan 5 siswa menyatakan biasa saja.

\section{c. Teknik pengajaran}

Teknik pengajaran mengacu pada prosedur atau strategi tertentu yang digunakan untuk mencapai tujuan pengajaran. Ada beberapa teknik yang dipakai oleh guru tersebut, diantaranya Listen-Do, Listen-Repeat dan Tanya Jawab. Maksud dari teknik tersebut adalah untuk mengenalkan kosakata baru dan mengetahui pemahaman siswa.

Listen-Do digunakan ketika memberikan kalimat-kalimat perintah pada siswa. Contoh ketika guru berkata "ok students, raise your hand (angkat tangan)", kemudian para siswa akan angkat tangan. Contoh lain ketika guru ingin memberikan materi baru di buku, lalu dia berkata, "open page 15" sambil membuka buku tersebut dan menunjukkan halamannya

Listen-Repeat digunakan untuk mengenalkan kosakata baru dengan pengucapan yang tepat. Teknik ini biasanya ada di tengah-tengah pembelajaran. Guru tesebut meyakini bahwa dengan adanya pengulangan yang terus menerus akan membuat pengucapan siswa semakin bagus dan tepat. Untuk mengetahui sejauh mana pemahaman siswa, guru tersebut menggunakan teknik Tanya jawab. Teknik ini ada di akhir pembelajaran. Guru bertanya dan murid yang bisa menjawab akan mendapatkan nilai sebagai reward.

Dan juga menggunakan teknik pengajaran Keterampilan berbicara dianggap keterampilan kedua dari empat keterampilan berbahasa, ia merupakan terjamah lisan tentang apa yang diketahui orang lewat menyimak, membaca dan menulis (Astuti \& Mustadi, 2014). Menyimak dan berbicara merupakan kegiatan berbahasa lisan. Kedua-duanya berkaitan dengan bunyi bahasa. Dalam menyimak seseorang mendapat informasi melalui ucapan atau suara. Dalam berbicara seseorang menyampaikan informasi melalui suara 
atau bunyi bahasa. Kegiatan menyimak pastilah didahului kegiatan berbicara, begitu pula berbicara biasanya disertai kegiatan menyimak. Mary dan Bonomo menanami keterampilan menyimak dan berbicara sebagai komunikasi (Arianto, 2018).

Proses belajar berbicara dalam bahasa asing akan menjadi mudah jika pembelajar secara aktif terlibat dalam upaya-upaya untuk berkomunikasi. Kita belajar membaca dengan membaca, karenanya kita belajar berbicara dengan berbicara. Namun, tidaklah berarti bahwa kita tidak diperkenankan untuk melibatkan pembelajar dalam aktivitas latihan manipulatif.

\section{Media}

Media memiliki peranan penting dalam proses kegiatan belajar mengajar. Hal ini membantu guru memberikan pemahaman lebih kepada siswa. Media juga berfungsi untuk mendukung siswa dalam belajar dan mengingat pentingnya konsep pelajaran. Dalam hal ini, media yang digunakan adalah gambar dan papan tulis.

Penggunaan media pembajaran sangat diperlukan dalam kaitannya dengan peningkatan mutu pendidikan khususnya dalam pembelajaran membaca puisi. Menurut Achsin menyatakan bahwa tujuan penggunaan media pengajaran adalah

a. Agar proses belajar mengajar yang sedang berlangsung dapat berjalan dengan tepat guna dan berdaya guna,

b. Untuk mempermudah bagi guru/pendidik daiam menyampaikan informasi materi kepada anak didik,

c. Untuk mempermudah bagi anak didik dalam menyerap atau menerima serta memahami materi yang telah disampaikan oleh guru/pendidik,

d. Untuk dapat mendorong keinginan anak didik untuk mengetahui lebih banyak dan mendalam tentang materi atau pesan yang disampaikan oleh guru/ pendidik,

e. Untuk menghindarkan salah pengertian atau salah paham antara anak didik yang satu dengan yang lain terhadap materi atau pesan yang disampaikan oleh guru/pendidik (Dewi \& Budiana, 2018).

Sedangkan Sudjana, dkk. menyatakan tentang

tujuan pemanfaatan media adalah :

a. Pengajaran akan lebih menarik perhatian siswa sehingga dapat menimbulkan motivasi,

b. Bahan pelajaran akan lebih jelas maknanya sehingga dapat lebih dipahami,

c. Metode mengajar akan lebih bervariasi, dan

d. Siswa akan lebih banyak melakukan kegiatan belajar (Al-Tabany, 2017)

Jadi dapat disimpulkan bahwa tujuan penggunaan media adalah

a) Efektivitas dan efisiensi dalam kegiatan belajar mengajar,

b) Meningkatkan motivasi belajar siswa, c) Variasi metode pembelajaran, dan

d) Peningkatan aktivasi siswa dalam kegiatan belajar mengajar.

Gambar digunakan untuk mengenalkan kosakata. Dia berkata, "what is this? Sambil menunjuk pada gambar tertentu" kemudian menunjuk satu atau dua siswa untuk menjawab. Gambar-gambar tersebut berasal dari buku, majalah, Koran, atau bahkan dari internet.

Papan tulis adalah media yang paling sering digunakan. Papan digunakan untuk mencatat materi ataupun menggambar sesuatu. Media ini juga digunakan untuk memberikan nilai ketika sedang berlangsung kuis.

\section{Pembahasan}

a. Kualifikasi guru

Kualifikasi guru dalam kegiatan belajar mengajar menentukan tercapainya tujuan pembelajaran. Ketrampilan dalam pekerjaan profesi sebagai guru didukung oleh teori yang telah dipelajari, seorang guru yang kompoten diharuskan untuk belajar terus menerus dan mendalami fungsinya sebagai guru yang memiliki kualifikasi. Karena guru yang profesional, mereka harus memiliki ketrampilan, kemampuan khusus, mencintai pekerjaannya, dan menjaga kode etik guru (Erwinsyah, 2017). Guru yang profesional, memiliki skil dalam pekerjaan sebagai pendidik. Sebagai pendidik tidak bosan dengan profesinya sebagai guru, menganggap pekerjaan itu sebagai hobi dan tidak merasa puas dengan apa yang dimiliki tentang seluk beluk pendidikan secara khusus dalam kegiatan belajar mengajar, dan menjaga sikap sebagai pendidik.

Adanya kualifikasi akan mendorong seseorang untuk mempunyai suatu keahlian atau kecakapan secara khusus. Kualifikasi di dalam dunia pendidikan dimengerti sebagai keahlian atau kecakapan khusus di bidang pendidikan. Keahlian ini adalah sebagai pengajar mata pelajaran, sebagai administrasi pendidikan dan lain sebagainya.

Kualifikasi guru terkadang bisa dilihat dari segi lulusannya. Kualifikasi untuk guru akan berbeda contohnya untuk guru SD, guru SMP atau guru SMA. Tentu berbeda sesuai dengan jenjang dan tingkatan. Demikian juga untuk guru yang mengajar di bangku kuliah maka akan dibutuhkan kualifikasi yang juga berbeda.

Selain kualifikasi guru, juga dibutuhkan kompetensi untuk didapat guru yang profesional. Kompetensi adalah seperangkat tindakan yang cerdas dan penuh tanggungjawab yang dimiliki oleh seseorang sebagai syarat agar dianggap mampu oleh masyarakat guna menjalankan tugas di bidang pekerjaan tertentu. Dari definisi tersebut maka kompetensi bisa digambarkan sebagai 
kemampuan untuk menjalankan satu tugas dan peran, kemampuan mengintegrasikan pengetahuan, ketrampilan, sikap dan nilai pribadi untuk membangun pengetahuan serta keterampilan yang berdasarkan pada pengalaman serta pembelajaran yang dijalankan.

Kualifikasi untuk seorang guru bisa dilihat sebagai suatu pekerjaan yang memerlukan kemampuan yang cakap. Kualifikasi guru berbeda sesuai pada setiap tingkat masing-masing. Kualifikasi adalah keahlian yang diperlukan untuk melakukan sesuatu, atau menduduki jabatan tertentu. alam dunia pendidikan, kualifikasi dimengerti sebagain keahlian atau kecakapan khusus dalam bidang pendidikan, baik sebagai pengajar mata pelajaran, administrasi pendidikan dan seterusnya. Bahkan, kualifikasi terkadang dapat dilihat dari segi derajat lulusannya.

Guru profesional harus memenuhi kriteria dari segi kualifikasi dan kompetensi yang dibuktikan dengan sertifikat profesional. Artinya guru pada tiap satuan pendidikan harus memenuhi kualifikasi akademik dengan bidang keilmuan yang relevan dengan bidang studi atau mata pelajaran yang mereka ajarkan di sekolahnya sehingga mereka disebut kompeten untuk bidang pekerjaannya. Persoalannya banyak guru pada jenjang pendidikan dasar yang memperoleh kesarjanaannya di luar bidang studi atau mata pelajaran yang diampu. Tentu saja guru dengan kualifikasi seperti itu, menurut peraturan perundangan belum bisa dikatakan guru profesional.

Adanya kualifikasi akan mendorong seseorang untuk mempunyai suatu keahlian atau kecakapan secara khusus. Kualifikasi di dalam dunia pendidikan dimaknai sebagai keahlian atau kecakapan khusus di bidang pendidikan. Keahlian ini adalah sebagai pengajar mata pelajaran, sebagai administrasi pendidikan dan lain sebagainya.

Selain kualifikasi guru, juga dibutuhkan kompetensi untuk didapat guru yang profesional. Kompetensi adalah seperangkat tindakan yang cerdas dan penuh tanggungjawab yang dimiliki oleh seseorang sebagai syarat agar dianggap mampu oleh masyarakat guna menjalankan tugas di bidang pekerjaan tertentu. Dari definisi tersebut maka kompetensi bisa digambarkan sebagai kemampuan untuk menjalankan satu tugas dan peran, kemampuan mengintegrasikan pengetahuan, ketrampilan, sikap dan nilai pribadi untuk membangun pengetahuan serta keterampilan yang berdasarkan pada pengalaman serta pembelajaran yang dijalankan.

Dari hasil wawancara, guru Bahasa Inggris adalah Iulusan Universitas Terbuka. Dia mengambil jurusan S-1 PGSD (Pendidikan Guru Sekolah Dasar). Selain dia mendapatkan materi Bahasa Inggris untuk usia dini di perkuliahannya, dia pun mendapatkan kompetensi bahasa Inggris dari kursus selama satu tahun. Namun, dia tidak pernah ikut seminar atau workshop tentang pengajaran Bahasa Inggris untuk usia dini untuk menambah pengetahuannya.

Berkaitan dengan pengalaman mengajar, dia sudah mengajar di sekolah tersebut selama enam tahun dan juga mengajar di sekolah tingkat pertama. Bisa dikatakan bahwa dia cukup layak untuk mengajar bahasa inggris.

b. Sikap siswa terhadap Bahasa Inggris

Dari 26 siswa, 23 diantaranya sangat ingin bisa berbicara Bahasa Inggris. Guru Bahasa Inggris bisa memotivasi mereka untuk terus belajar dan jangan lupa guru juga harus mengembangkan ataupun memperbaharui cara mengajarnya. Hal ini bertujuan agar siswa tidak bosan dan lebih mudah interaksi pada saat kegiatan belajar mengajar.

Sedangkan dari hasil kuesioner, didapatkan 14 siswa menikmati materi dan proses pengajaran dan pembelajaran. Perlunya guru tersebut untuk mengembangkan materi sehingga tercipta suasana yang kondusif di kelas dan membuat siswa bahagia. Dari itu juga diketahui bahwa 12 siswa terkadang aktif dalam bertanya dikelas. Dengan keadaan seperti ini, tentunya, guru harus bisa memberikan stimulus bagi siswa untuk lebih aktif lagi dalam bertanya. Misalkan dengan memberikan poin tersendiri atau berupa reward tertentu sehingga siswa bisa lebih aktif dalam bertanya.

Begitu juga, perlunya ada suasana yang aman. Dalam artian, ketika ada seorang siswa yang bertanya dan salah, terkadang siswa yang lain akan menertwakannya. Hal ini membuat siswa tersebut kehiilangan rasa percaya diri. Guru selaku ujung tombak dikelas, perlu memberikan pemahaman bahwa kesalahan tidak harus ditertawakan akan tetapi diperbaiki.

Sebagian besar siswa juga menganggap bahwa Bahasa Inggris penting bagi masa depan mereka (20 siswa). Kesadaran mereka sudah tampak dan perlu didukung dan diberi semangat untuk terus belajar. Salah satu factor siswa berhasil dalam belajarnya adalah akrena adanya kemauan yang kuat.

Hasil diatas bisa menjadi referensi bagi guru untuk merancang pembelajaran yang menyenangkan dikelas. Pun penting bagi guru untuk mengetahui gaya belajar siswa sehingga penyampaian materi bisa menyesuaikan dengan gaya belajar tersebut.

c. Teknik Pengajaran 
Teknik adalah cara yang dilakukan seseorang dalam rangka mengimplementasikan suatu metode. Misalnya, cara yang bagaimana yang harus dilakukan agar metode ceramah yang dilakukan berjalan efektif dan efisien? Dengan demikian sebelum seorang melakukan proses ceramah sebaiknya memperhatikan kondisi dan situasi.

Teknik yang digunakan ada tiga, yaitu listendo, listen-repeat, dan Tanya jawab. Berdasarkan hasil wawancara, teknik ini sangatlah membantu siswa dalam memahami materi pembelajaran serta memciptakan suasana yang kondusif di kelas.

Listen-do digunakan guru dalam memberikan perintah yang sesuai dengan keadaan (real instruction). Para siswa membutuhkan latihan dan pembiasaan tentang perintah-perintah yang digunakan sehari-hari dikelas. Seperti "open your book, sit down, erase the blackboard, etc". Scott and Ytreberg (1990) berpendapat bahwa banyak keuntungan dari kegiatan seperti ini. Pertama, guru bisa mengetahui siswa yang sudah atau belum paham akan materi. Kedua, guru tersebut bisa memberikan pemahaman kepada siswa lain. Dan yang terakhir, bagi siswa yang belum bisa, mereka akan meniru temannya yang sudah menguasai (Krisdiana, Apriandi, \& Setyansah, 2014).

Sedangkan dalam teknik listen-repeat, tugasnya siswa hanyalah mendengarkan apa yang dibicarakan oleh guru. Kemudian guru meminta siswa untuk mengulangi apa yyang sudah diperdenagrkan. Dia melakukannya di pertengahan pembelajaran dan dimulai dengan kosakata sampai kalimat sederhana.

Dan yang terakhir adalah teknik Tanya jawab. Teknik ini bertujuan untuk mengetahui pemahaman siswa terhadap materi yang sudah disampaikan. Kegiatan ini sangat berguna untuk listening dan speaking skill. Pemahaman anak usia dini tidak hanya berasal dari penjelasan guru akan tetapi juga berasal dari apa yang mereka lihat dan dengar (Harmer, 2008).

Selama proses pengajaran dan pembelajaran, guru selalu menerima setiap pertanyaan siswa baik dalam bahasa Indonesia ataupun bahasa daerah tanpa langsung mengoreksi. Hal ini tentunya akan memberikan dampak positif dikelas dan akan menciptakan suasana kelas yang bagus. Koreksi digunakan ketika guru memberikan latihan/soal bukan pada saat guru menggunakan bahasa sebagai alat komunikasi (Gintings \& Si, 2010).

d. Media

Media pembelajaran secara umum adalah alat bantu proses belajar mengajar. Segala sesuatu yang dapat dipergunakan untuk merangsang pikiran, perasaan, perhatian dan kemampuan atau ketrampilan pebelajar sehingga dapat mendorong terjadinya proses belajar.

Media pembelajaran adalah sarana fisik untuk menyampaikan isi/materi pembelajaran seperti : buku, film, video dan sebagainya (Akbar, 2018). Kemudian menurut National Education Associaton (1969) mengungkapkan bahwa media pembelajaran adalah sarana komunikasi dalam bentuk cetak maupun pandang-dengar, termasuk teknologi perangkat keras. Oleh karena proses pembelajaran merupakan proses komunikasi dan berlangsung dalam suatu sistem, maka media pembelajaran menempati posisi yang cukup penting sebagai salah satu komponen sistem pembelajaran. Tanpa media, komunikasi tidak akan terjadi dan proses pembelajaran sebagai proses komunikasi juga tidak akan bisa berlangsung secara optimal. Media pembelajaran adalah komponen integral dari sistem pembelajaran

Hamalik (1986) mengemukakan bahwa pemakaian media pengajaran dalam proses belajar mengajar dapat membangkitkan keinginan dan minat yang baru, membangkitkan motivasi dan rangsangan kegiatan belajar, dan bahkan membawa pengaruh-pengaruh psikologis terhadap siswa (Karo-Karo \& Rohani, 2018).

Guru menggunakan media berkaitan dengan topik yang diberikan untuk menarik perhatian siswa. Richard (1988) dalam Sukesi (2004) menyatakan bahwa media digunakan untuk mengembangkan minat ketika guru menyampaikan materi (Zahro, 2016). Dalam hal ini, gambar sangat membantu pengajarannya. Untuk mengetahui pemahaman siswa, dia bisa menggunakan media yang dia buat sendiri.

Penggunaan media membawa pengaruh terhadap peserta didik. Media yang digunakan oleh guru disesuiakan dengan peserta didik dan guru juga mampu menggunakan media tersebut. Media yang dipilih harus tepat, memadai, dan mudah digunakan (Sumiharsono \& Hasanah, 2017). Dalam menggunakan media guru menyesuaikan dengan tingkat pemahaman dan pengetahuan anak yang mudah untuk dimengerti. Bagi guru juga bisa menggunakan media tersebut tanpa adanya kesulitan yang membuat suasana kelas tidak nyaman.

\section{Kesimpulan}

Pertama tentang kualifikasi guru. Guru Bahasa Inggris sudah memenuhi kualifikasi. Dia lulusan universitas terbuka dan PGSD sebagai jurusannya. Materi tentang pengajaran Bahasa Inggris untuk usia dini dia dapatkan sewaktu kuliah. Sedangkan 
tambahan materi Bahasa Inggris lainnya dia peroleh ketika mengikuti kursus.

Kedua, kebanyakan dari siswa sangat menginginkan bisa berbicara Bahasa Inggris. Guru bisa memotivasi siswa untuk belajar Bahasa Inggris demi mencapai masa depan yang lebih baik. Apalagi didukung dengan adanya kesukaan siswa terhadap gaya mengajar guru tersebut. Walaupun terkadang semangat mereka pasang surut. Namun tidak menutup mereka untuk menikmati materi Bahasa Inggris dikelas.

Ketiga, teknik yang digunakan sudah bagus. Dengan memberikan praktik langsung kepada siswa untuk berkomunikasi dengan Bahasa Inggris. Hal in tentunya akan mendorong siswa untuk lebih semangat lagi belajarnya.

Yang terakhir, media yang digunakan sudah bisa menstimulus siswa untuk belajar Bahasa Inggris. Gambar-gambar yang berkaitan dengan materi akan memberikan pengalaman pertama bagi siswa dalam menangkap pesan yang ingin disampaikan oleh guru. Dan tak lupa juag penggunaan papan tulis secara maksimal memudahkan siswa mencatat materi baru.

\section{References}

Akbar, R. R. A. (2018). Pengembangan Video Pembelajaran Matematika Berbantuan Media Sosial Instagram sebagai Alternatif Pembelajaran. UIN Raden Intan Lampung.'

Al-Tabany, T. I. B. (2017). Mendesain Model Pembelajaran Inovatif, Progresif, Dan Konteksual. Prenada Media.

Arianto, A. (2018). Model Pembelajaran Terpadu Untuk Meningkatkan Keterampilan Menyimak Dan Berbicara. Al-Izzah: Jurnal Hasil-Hasil Penelitian, 13(1), 48-62.

Astuti, Y. W., \& Mustadi, A. (2014). Pengaruh penggunaan media film animasi terhadap keterampilan menulis karangan narasi siswa kelas V SD. Jurnal Prima Edukasia, 2(2), 250-262.

Dewi, P. K., \& Budiana, N. (2018). Media pembelajaran bahasa: aplikasi teori belajar dan strategi pengoptimalan pembelajaran. Universitas Brawijaya Press.

Erwinsyah, A. (2017). Manajemen Pembelajaran Dalam Kaitannya Dengan Peningkatan Kualitas Guru. Tadbir: Jurnal Manajemen
Pendidikan Islam, 5(1), 69-84.

Gintings, A., \& Si, M. (2010). Esensi Praktis Belajar \& Pembelajaran: Disiapkan untuk Pendidikan Profesi dan Sertifikasi GuruDosen. Humaniora Utama Press.

Harmer, J. (2008). How to teach English. ELT Journal, 62(3), 313-316.

Karo-Karo, I. R., \& Rohani, R. (2018). Manfaat media dalam pembelajaran. AXIOM: Jurnal Pendidikan Dan Matematika, 7(1).

Krisdiana, I., Apriandi, D., \& Setyansah, R. K. (2014). Analisis kesulitan yang dihadapi oleh guru dan peserta didik sekolah menengah pertama dalam implementasi Kurikulum 2013 pada mata pelajaran matematika (studi kasus eks-karesidenan Madiun). JIPM (Jurnal IImiah Pendidikan Matematika), 3(1).

Rijal, S., \& Bachtiar, S. (2015). Hubungan antara sikap, kemandirian belajar, dan gaya belajar dengan hasil belajar kognitif siswa. Jurnal Bioedukatika, 3(2), 15-20.

Sumiharsono, R., \& Hasanah, H. (2017). Media Pembelajaran: Buku Bacaan Wajib Dosen, Guru dan Calon Pendidik. Pustaka Abadi.

Zahro, R. N. (2016). Pengembangan Flip Book Materi Sel di SMA. Universitas Negeri Semarang. 